\title{
BETA-CASEIN GENE POLYMORPHISM IN SERBIAN HOLSTEIN-FRIESIAN COWS AND ITS RELATIONSHIP WITH MILK PRODUCTION TRAITS
}

\author{
RISTANIC Marko $^{1 *}$, GLAVINIC Uros ${ }^{1}$, VEJNOVIC Branislav ${ }^{2}$, \\ MALETIC Milan ${ }^{3}$, KIROVSKI Danijela ${ }^{4}$, TEODOROVIC Vlado ${ }^{5}$, \\ STANIMIROVIC Zoran ${ }^{1}$
}

\begin{abstract}
${ }^{1}$ Department of Biology, Faculty of Veterinary Medicine, University of Belgrade, Bul. Oslobodjenja 18, Belgrade, Serbia; ${ }^{2}$ Department of Economics and statistics, Faculty of Veterinary Medicine, University of Belgrade, Bul. Oslobodjenja 18, Belgrade, Serbia; ${ }^{3}$ Department of Reproduction, Fertility and Artificial Insemination, Faculty of Veterinary Medicine, University of Belgrade, Bul. Oslobodjenja 18, Belgrade, Serbia; ${ }^{4}$ Department of Physiology and Biochemistry, Faculty of Veterinary Medicine, University of Belgrade, Bul. Oslobodjenja 18, Belgrade, Serbia; ${ }^{5}$ Department of Food Hygiene and Technology, Faculty of Veterinary Medicine, University of Belgrade, Bul. Oslobodjenja 18, Belgrade, Serbia
\end{abstract}

(Received 19 March, Accepted 17 July 2020)

The most common types of beta-casein in cow's milk are A1 and A2, which differ in one amino acid. During the gastrointestinal proteolysis of A1 beta-casein in humans this difference results in the release of beta-casomorphin-7, an opioid which may lead to severe effects on human health, causing various ailments (type-1 diabetes mellitus, ischemic heart disease, arteriosclerosis, sudden infant death syndrome, autism, schizophrenia, gastrointestinal digestive discomfort, as well as increased gastrointestinal transit time). By contrast, A2 beta-casein cannot exert these effects owing to its different composition and metabolism. Furthermore, studies have shown that it can influence milk productivity traits. Our research aimed to screen the frequency of A1 and A2 alleles of beta-casein gene in a population of Serbian Holstein-Friesian cows and to detect how the genotypes influence milk production, and milk protein and fat yields. Out of 106 animals, $13(12.26 \%)$ were of A1A1 genotype, $58(54.72 \%)$ of A1A2, and $35(33.02 \%)$ of A2A2 genotype. Milk yield was significantly $(\mathrm{P}<0.01)$ higher in A2A2 compared to both A1A1 and A1A2 genotypes. Milk protein concentrations were significantly $(\mathrm{P}<0.01)$ higher in A2A2 compared to A1A2 genotype, while milk fat concentrations were significantly $(\mathrm{P}<0.01)$ higher in A2A2 compared to both A1A1 and A1A2 genotypes.

Key words: Holstein-Friesian, beta-casein, allele frequency, genotype frequency, RFLP-PCR, milk productivity traits

\footnotetext{
*Corresponding author: e-mail: mristanic@vet.bg.ac.rs
} 


\section{INTRODUCTION}

Cow's milk is generally considered to be a highly esteemed foodstuff in human diet, given that it contains essential nutrients, including proteins, carbohydrates, minerals and vitamins. It consists of $3.5 \%$ proteins, $80 \%$ of which are alpha $S 1$, beta- $(\beta)$, alpha S2 and kappa- $(x)$ casein (CSN1S1, CSN2, CSN1S2 and CSN3), while the remaining $20 \%$ are whey proteins ( $\alpha$-lactalbumin and $\beta$-lactoglobulin) [1]. Milk proteins are undoubtedly one of the important sources of amino acids in the human diet and therefore have a significant impact on the health of milk consumers [1-5]. Among the caseins mentioned, beta-casein is the second most abundant protein. What makes it significant is its excellent nutritional balance of amino acids. Beta-casein accounts for $25-30 \%$ of total cow's milk protein and consists of 209 amino acids. The bovine beta-casein gene belongs to a cluster of four casein genes, which are located on chromosome number six [6]. Certain authors state that there are at least 12 genetic variants of beta-casein: A1, A2, A3, B, C, D, E, F, H1, H2, I, and G [1,7-9]. Out of these beta-casein variants, the $\mathrm{A} 1$ and $\mathrm{A} 2$ types are by far the most prevalent. It is considered that A2 beta-casein is the original beta-casein protein because it was present before the mutation caused the emergence of A1 beta-casein in European cattle (Bos taurus), several thousand years ago [10]. The difference between A1 and A2 beta-casein lies in their amino acid chain composition in position 67: in the former there is histidine and in the latter there is proline. This difference results from the single nucleotide polymorphism (SNP) at codon 67, which is CCT (A2, proline) or CAT (A1, histidine). Therefore, cows with A2A2 genotype produce milk containing A2 beta-casein, unlike cows with A1A1 and A1A2 genotypes, which synthesise A1 beta-casein. The polymorphism that caused the replacement of proline with histidine leads to critical changes in the secondary conformation of the expressed beta-casein gene [5,11]. The presence of histidine causes the release of a bioactive peptide called beta-casomorphin-7 (BCM-7) in the process of gastrointestinal proteolysis of A1 beta-casein in the small intestine of humans, while the presence of proline in A2 protein in position 67 prevents the polypeptide sequence from breaking at this critical site. Thus, it forms another peptide called beta-casomorphin-9 (BCM-9) [1214] rather than BCM-7. Due to its low molecular weight, BCM-7 crosses the bloodbrain barrier and binds to $\mu / \mathrm{k} / \delta$ receptors localized in the central nervous system, gastrointestinal system and some components of the immune system. Previously, milk was thought to be exclusively a source of macronutrients, but studies suggest that casein-derived bioactive peptides (such as BCM-7) can have a significant impact on consumer health [12-21]. Studies also suggest a correlation between the consumption of milk containing A1 beta-casein and the incidence of human diseases such as type-1 diabetes mellitus, ischemic heart disease [15], arteriosclerosis [16], sudden infant death syndrome [17], autism, schizophrenia [18], gastrointestinal digestive discomfort [19,20] as well as increased gastrointestinal transit time [21]. Furthermore, many researchers have investigated the negative impact of A1 beta-casein on the gastrointestinal passage and on inflammatory responses in the gastrointestinal system in mice and rats 
[8,19,22-24]. Research detected positive influence of the A2 allele of the beta-casein gene on the milk and milk protein yield, but also the decrease in milk fat yield [2531]. The identification of genetic markers for economically important traits in farm animals has intrigued the scientific community for years. Thus, bovine chromosome number 6 (BTA6) is one of the main research objects of many scientists interested in Quantitative Trait Loci (QTL) related to milk production traits. Analyses have shown that BTA6 harbours at least 77 QTLs, 48 of which are responsible for milk yield and milk protein composition [32]. The results by Schopen et al. [33] revealed that 3.5\% of the phenotypic variance for milk protein composition probably depends on the polymorphism of the beta-casein gene. Therefore, the preference for A2 allele in cattle breeding could have several positive implications, primarily for human health, but also for milk and milk constituents' yield.

Having in mind that Holstein-Friesian (HF) breed is one of the most common dairy cattle breeds in Serbia, our research aimed to screen the presence of A1 and A2 alleles of beta-casein gene in a population of Serbian HFs and investigate how the detected genotypes influence milk yield, and milk protein and fat concentrations. This is expected to deepen the understanding of this problem, and contribute to better cattle breeding and selection programs and healthier milk in Serbia by reducing A1 allele frequency in the population of Serbian cows.

\section{MATERIAL AND METHODS}

\section{Ethics statement}

This research has been complied with all the relevant national regulations and institutional policies for the care and use of animals - Ministry of Agriculture, Forestry and Water Management of the Republic of Serbia, Decision No: 323-07-06299/201805 issued on 23 July 2018.

\section{Investigated group of animals}

Animals used in this experiment were HF cows kept at the Al Dahra Corporation (Former PKB corporation), Farm Unit Kovilovo, in the vicinity of Belgrade, Serbia. The investigation included $106 \mathrm{HF}$ cows, 4-5 years old, kept under the same conditions, in a tied-stall housing system, and fed on the same diet. Data on milk yield, milk protein concentrations and milk fat concentrations were collected for all animals for the period 2016-2019. The practice on this farm is to monitor the mammary complex and the general health status every day, while California Mastitis Test (CMT) is carried out on a monthly basis. Bacteriological analyses of milk are done periodically. All animals were well-conditioned and without significant health problems during the course of the study. 


\section{Data collection}

Data on milk yield, and milk protein and milk fat concentrations were collected after the cows completed their second lactation. The data on milk yield were collected from the farm's database, which keeps record for each cow on a daily basis. Once a month a specialized laboratory conducts biochemical analyses of milk produced on the farm. These data were processed in our research.

\section{Sample Collection}

Blood samples were acquired by venepuncture of $v$. coccygea with sterile needles and put in tubes containing an anticoagulant (EDTA). From each animal, at least $10 \mathrm{ml}$ of blood was obtained. The samples were kept in a portable refrigerator during transportation to the laboratory, and the extraction of DNA was carried out on their arrival.

\section{DNA extraction and quantification}

DNA extraction was carried out using Quick-gDNA TM MiniPrep commercial kit, in compliance with the producer's protocol. In order to confirm the quality and quantity of the samples, they were quantified using BioSpec-nano UV-VIS Spectrophotometer. The samples that showed an optical density (OD) ratio $(260 \mathrm{~nm} / 280 \mathrm{~nm})$ of between 1.8 and 2.2 were kept for further analyses, and diluted to a concentration of $30 \mathrm{ng} / \mu \mathrm{L}$.

\section{PCR amplification of beta-casein gene region}

The molecular technique chosen for the study was Polymerase Chain Reaction - Restriction Fragment Length Polymorphism (PCR - RFLP) method. In order to amplify the desired sites of the gene, the primers reported by Lien et al [34] were used: CASB122L-5'GAGTCGACTGCAGAT'T'TCAACATCAGTGAGAGTCA GG CCCTG 3' and CASB67R-5'CCTGCAGAATTCTAGTCTATCCCTTCCCTGGGC CCATCG 3'. The primers were mismatched at their 3' end, which enables them to end just before the point mutation in beta-casein gene. CASB122 primer has a mismatch of C-A in the fourth last position and CASB67 primer had a G-G mismatch in the last position of the 3' end [34]. These primers had the amplification-created restriction sites (ACRS), which were created artificially by allele-specific site-directed mutagenesis in the amplification step in order to identify various genotypes in the investigated cows. PCR amplification was conducted in a MultiGene Gradient (Labnet International Inc.) machine in order to produce a 251-bp fragment in the case of exon 7 in beta-casein gene. The PCR mix was initially composed following the producer's manual of KAPA Taq PCR Kit (Kapa Biosystems) and its suggested primer annealing temperature. Later on, the ratio of the PCR mix components was optimized in order to obtain clearer bands on the electrophoreogram. Therefore, final PCRs were performed in the total volume of $25 \mu \mathrm{l}$ using KAPA Taq PCR Kit with 10X KAPA Taq Buffer, 25 $\mathrm{mM} \mathrm{MgCl}, 10 \mathrm{mM}$ dNTP Mix, $0.8 \mu \mathrm{M}$ of each primer, $0.5 \mathrm{U}$ of KAPA Taq DNA 
Polymerase and $180 \mathrm{ng}$ of DNA sample. PCR conditions involved initial denaturation at $95^{\circ} \mathrm{C}$ for $3 \mathrm{~min}$, followed by 35 cycles of denaturation at $95^{\circ} \mathrm{C}$ for $30 \mathrm{sec}$, primer annealing at $64.3^{\circ} \mathrm{C}$ for $30 \mathrm{sec}$, extension at $72^{\circ} \mathrm{C}$ for $1 \mathrm{~min}$ and final extension at $72^{\circ} \mathrm{C}$ for 1 min. PCR products $(5 \mu \mathrm{l})$ were mixed with $1.0 \mu \mathrm{l}$ 6X DNA Loading Dye (Thermo Scientific, USA). The amplification products were analysed using electrophoresis in $2 \%$ agarose gel and stained with SimplySafe ${ }^{\mathrm{TM}}$ (EURx Ltd.), visualized with UV light and documented. In order to disengage the restriction fragments, PCR products were digested using Fast Digest TaqI Enzyme (Thermo Scientific, USA) at $65^{\circ} \mathrm{C}$ for 5 min. Following incubation, the digested products $(5 \mu \mathrm{l})$ were mixed with $1.0 \mu \mathrm{l}$ 6X DNA Loading Dye (Thermo Scientific, USA), subjected to electrophoresis in $2 \%$ agarose gel, stained with SimplySafe ${ }^{\mathrm{TM}}$ (EURx Ltd.), photographed under UV illumination and examined for different band patterns.

\section{Statistical analyses}

Genetic equilibrium of the investigated population of cows was estimated using the Hardy-Weinberg principle and analysed with the chi-square test. Based on homogeneity of the data $(\mathrm{CV}<30 \%)$ for milk production traits (milk yield, and protein and fat content), groups were compared using two-way ANOVA with repeated measures in one factor, followed by Tukey's multiple comparisons test between groups and Sidak's multiple comparisons test within groups. Statistical analysis of the results obtained in the research was carried out using statistical software GraphPad Prism version 6 (GraphPad, San Diego, CA, USA).

\section{RESULTS}

In this study, the presence of the beta-casein gene types was examined in a population of $106 \mathrm{HF}$ cows. The analysis of band patterns on gel electrophoresis distinguished three different genotypes: A1A1, A1A2 and A2A2. In Figure 1 gel electrophoresis is shown: the bands representing products sized 251 base pairs (bp) correspond to genotype A2A2, those sized 213 and 38 bp correspond to genotype A1A1, while the electrophoretic bands representing products sized 251, 213 and 38 bp are of A1A2 genotype. Among 106 experimental cows, 13 were of A1A1 genotype, 58 of A1A2 genotype, while 35 animals were of A2A2 genotype (Table 1). The results of the detected genotype frequencies of beta-casein polymorphism comply with the HardyWeinberg equilibrium. Milk yield and the content of milk proteins and fat in cows of different beta-casein genotypes were compared in two ways: A - within the first and second lactations, considered separately; B - within the group of the same genotype, between the first and second lactation. Furthermore, the mean values were compared taken in consideration the production in both lactations together. Analysis of milk production in the first lactation revealed significant differences between A1A1 vs A1A2 $(\mathrm{P}<0.05), \mathrm{A} 1 \mathrm{~A} 1$ vs A2A2 ( $<0.01)$ and A1A2 vs A2A2 ( $<0.01)$ genotypes, while in the second lactation the differences were proven to be not significant $(\mathrm{P}>0.05$, Figure 
2A). There was a significant increase in the amounts of produced milk in the second lactation in comparison with the first one in cows of A1A1 and A1A2 genotypes $(\mathrm{P}<0.01)$, but not in those of $\mathrm{A} 2 \mathrm{~A} 2(\mathrm{P}>0.05$, Figure $2 \mathrm{~B})$. When the first and second lactations were considered together (Table 2) and the genotypes compared for milk quantity in both of them (Table 3), A1A1 (7727.92 L on average) and A1A2 (8174.02 $\mathrm{L})$ genotypes did not differ significantly $(\mathrm{P}>0.05)$. However, within the remaining two combinations of genotypes, A1A1 vs A2A2 (9315.59 L) and A1A2 vs A2A2, the differences in the results were significant $(\mathrm{P}<0.01)$. Differences in milk protein concentrations were significant only within the second lactation between A1A2 vs A2A2 genotype $(\mathrm{P}<0.01$, Figure $3 \mathrm{~A})$. However, when the total milk production was assessed in both lactations (Table 3), significant differences were detected between A1A2 (3.13\% on average, Table 2$)$ vs A2A2 $(3.19 \%$, Table 2$)$ genotypes $(\mathrm{P}<0.01)$ only, while the differences A1A1 (3.16\%, Table 2) vs A1A2, and A1A1 vs A2A2 were proved insignificant $(\mathrm{P}>0.05)$. The average milk protein concentrations were significantly higher in the second lactation $(\mathrm{P}<0.01$, Figure $3 \mathrm{~B})$, regardless of the genotype detected. In both the first and the second lactation milk fat concentrations were highest if produced by A2A 2 cows and differed significantly in comparison with $\mathrm{A} 1 \mathrm{~A} 1$ and $\mathrm{A} 1 \mathrm{~A} 2$ genotypes $(\mathrm{P}<0.01)$, and $\mathrm{A} 1 \mathrm{~A} 2$ vs $\mathrm{A} 2 \mathrm{~A} 2$ in the first and second lactation, while there was no significance $(\mathrm{P}>0.05)$ of differences between other pairs of genotypes (Figure 4A). The results were identical (Table 3) when the data from both lactations were considered together (in A1A1 3.36\% on average, in A1A2 3.37\% and $3.44 \%$ in A2A2, Table 2). In cows of all of the three genotypes significantly higher milk fat concentrations were in the second lactation ( $\mathrm{P}<0.01$, Figure $4 \mathrm{~B})$.

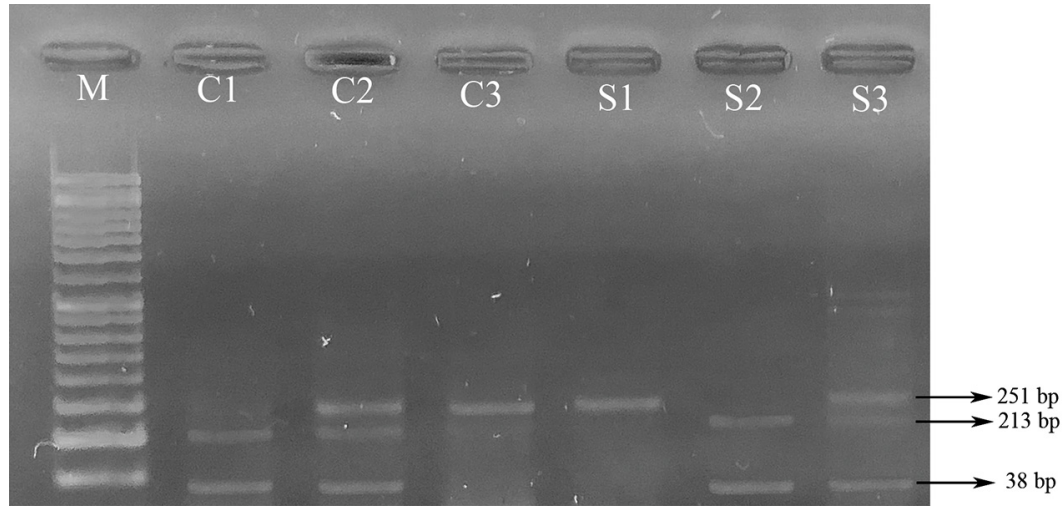

Figure 1. Polymerase Chain Reaction - Restriction Fragment Length Polymorphism (PCR RFLP) amplification results in 2\% agarose gel.

$\mathbf{M}$ - ladder (100 bp); C1 - A1A1 genotype control sample; C2 - A1A2 genotype control sample; C3 - A2A2 genotype control sample; S1 - sample 1; S2 - sample 2; S3 - sample 3. 

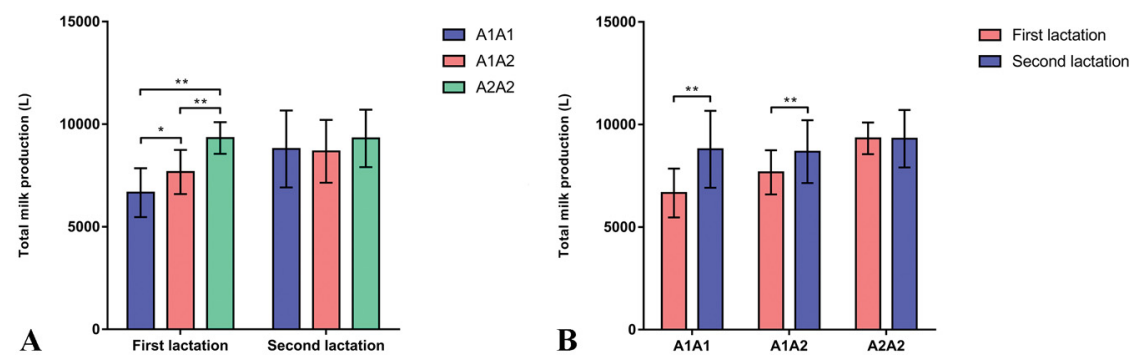

Figure 2. Milk yield (in litres).

A: Milk yields obtained from cows of different beta-casein genotypes compared within the first and the second lactation

B: Milk yield comparison between the first and second lactation in cows of the same betacasein genotype.
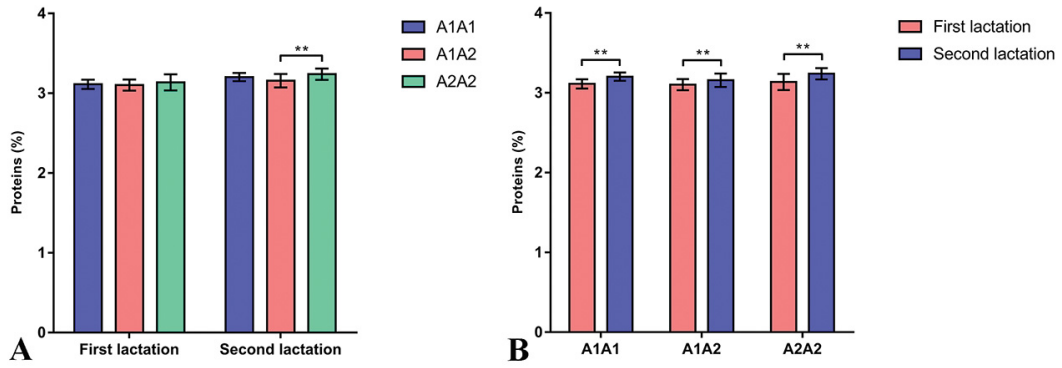

Figure 3. Milk protein concentrations (percentages).

A: Milk protein concentrations obtained from cows of different beta-casein genotypes compared within the first and the second lactation

B: Milk protein concentrations compared between the first and second lactation in cows of the same beta-casein genotype.
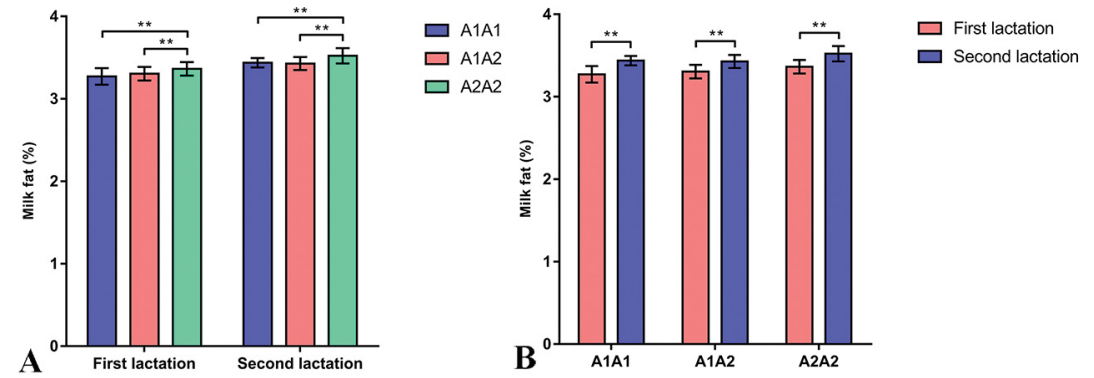

Figure 4. Milk fat concentrations (percentages).

A: Milk fat concentrations obtained from cows of different beta-casein genotypes compared within the first and the second lactation

B: Milk fat concentrations compared between the first and second lactation in cows of the same beta-casein genotype. 
Table 1. Beta-casein genotype and allelic frequencies

\begin{tabular}{cccccc}
\hline \multirow{2}{*}{ Beta-casein genotype } & N & $\begin{array}{c}\text { Genotype } \\
\text { frequency (\%) }\end{array}$ & \multicolumn{2}{c}{ Allelic frequency } \\
\cline { 5 - 6 } & & 13.26 & & A2 \\
\hline A1A1 & 13 & 54.72 & 0.396 & 0.604 \\
A1A2 & 58 & 33.02 & & \\
\hline A2A2 & 35 & & & \\
\hline
\end{tabular}

Table 2. Milk production traits in cows of different beta-casein genotypes

\begin{tabular}{lccc}
\hline Milk production trait & Genotype & Mean & St. Err. \\
\hline \multirow{3}{*}{ Total milk production (L) } & A1A1 & 7727.92 & 288.01 \\
& A1A2 & 8174.02 & 136.36 \\
& A2A2 & 9315.59 & 175.53 \\
Proteins (\%) & A1A1 & 3.16 & 0.02 \\
& A1A2 & 3.13 & 0.01 \\
Milk fat (\%) & A2A2 & 3.19 & 0.01 \\
& A1A1 & 3.36 & 0.02 \\
& A1A2 & 3.37 & 0.01 \\
& A2A2 & 3.44 & 0.01 \\
\hline
\end{tabular}

Table 3. Significance of differences in milk-production traits between various beta-casein genotypes (production in both lactations sonsidered together)

\begin{tabular}{lcc}
\hline Milk-production trait & $\begin{array}{c}\text { Tukey's multiple } \\
\text { comparisons test }\end{array}$ & Significance \\
\hline \multirow{3}{*}{ Total milk production (L) } & A1A1 vs. A1A2 & $\mathrm{ns}$ \\
& A1A1 vs. A2A2 & $* *$ \\
& A1A2 vs. A2A2 & $* *$ \\
Milk proteins (\%) & A1A1 vs. A1A2 & $\mathrm{ns}$ \\
& A1A1 vs. A2A2 & $\mathrm{ns}$ \\
& A1A2 vs. A2A2 & $* *$ \\
Milk fat $(\%)$ & A1A1 vs. A1A2 & $\mathrm{ns}$ \\
& A1A1 vs. A2A2 & $* *$ \\
& A1A2 vs. A2A2 & $* *$ \\
\hline
\end{tabular}

${ }^{* *} \mathrm{p}<0,01$, ns $=$ no significant difference 


\section{DISCUSSION}

Nowadays, we are witnessing an ever-expanding of the world's human population and therefore a greater need for food, globally. For the past few decades, many researchers have been dealing with the problem of rendering agricultural and livestock production more effective. Therefore, different methods are used to make animal breeding and animal selection programs more effective [35]. In this study, we investigated the genotype and allelic frequencies of beta-casein gene in 106 Serbian HF cows. The genotyping results showed higher A2 allelic frequency (0.604) than the frequency of A1 allele (0.396), which results from higher frequencies of A1A2 and A2A2 genotypes (54.72\% and $33.02 \%$, respectively, Table 1). The results of our investigation are consistent with those obtained on HF cattle throughout the European and Asian countries, which revealed lower A1 allelic frequency in comparison with that of A2 allele [31,33,37-41]. Our results are most similar to those obtained by Polish researchers on their HF cattle [42-44]. The reason for this similarity with other European countries could be the fact that in the 1960s the majority of HF sires in Serbia were imported from Central and Western Europe. These sires are the ancestors of the nowadays bulls used in artificial insemination programs of cows from which we collected the samples for our investigation. The relationship between various milk proteins, milk yield and milk composition (protein and fat concentrations) was assessed by different authors (beta-casein: [28,29,31,36,44,45]; kappa casein: [46,47]). In order to assess the relationship in Serbian HF cows we collected the relevant data for 106 animals. The results of statistical analysis done on the milk records considered for both lactations together pointed to significant differences in milk yield between the cows of different beta-casein genotypes - A1A1 vs A2A2 (P <0.01) and A1A2 vs A2A2 (P<0.01) suggesting that $\mathrm{A} 1$ allele was associated with lower milk production in the tested cows, which is in accordance with the results reported by Nislen et al. [28], Olenski et al. [44] and Visker et al. [31]. Milk protein concentration analyses showed significant $(\mathrm{P}<0.01)$ differences between cows with beta-casein genotype of A1A2 vs A2A2 (when the first and second lactation were considered together). However, when milk protein concentrations were compared between the two lactations, a significant increase was detected in the second one $(\mathrm{P}<0.01)$, regardless of the cows' genotype (A1A1, A1A2 or A2A2). Based on these findings, we can assume that A2 allele did not affect the milk protein concentrations in the investigated group of animals. These results differ from the findings reported by the majority of authors [28,31,44], who concluded that the A2 allele of beta-casein gene could be associated with higher milk yields and milk protein concentrations. Research conducted by Hanusova et al. [29] on Slovak HF cattle showed similar results to those obtained in our work: they found that cows of A2A2 beta-casein genotype produced milk with slightly higher protein concentration (3.28\% on average) than those of A1A1 (3.17\%) and A1A2 (3.20\%) genotypes. This is in accordance with our results of protein concentrations (A1A1 - 3.16\%, A1A2 $3.13 \%$ and A2A2 - 3.19\%), which did not differ significantly between the genotypes. The divergence of our results from those obtained by most authors could be owing 
to the lower number of animals included in our research. In our work, the differences in milk fat concentrations between the cows of A1A1 vs A2A2 and A1A2 vs A2A2 genotypes were proven to be significant $(\mathrm{P}<0.01$ for both comparisons). The same was revealed when the comparison was done within the first and second lactation considered separately, indicating that the presence of A2 allele positively affected milk fat yields in the tested animals. Our results are inconsistent with those obtained by Velmala et al. [25], Ikonen et al. [26,27], Nilsen et al. [28] and Olenski et al. [44], who found that A2 allele was not associated with higher milk fat concentrations. The results of milk fat concentrations in our study $(3.36 \%$ on average in A1A1 and $3.37 \%$ in A1A2) are in accordance with those obtained by Hanusova et al. [29], who recorded insignificantly higher milk fat concentrations in cows of A1A2 genotype $(3.90 \%)$ in comparison to those of A1A1 (3.77\%).

\section{CONCLUSIONS}

Recently, the interest in beta-casein polymorphism has been gaining popularity, at first among researchers, but later among milk producers and consumers, as well. The main reason for this can be found in the emerging data on the association between certain genetic variants of casein and human nutrition and health, which has been reported by many authors. However, to clarify the definitive effects of A1 and A2 genetic variants on human health, further investigations were required. Our results confirm earlier studies that different types of beta-casein are associated with higher milk yields. Due to inconsistency in literature related to the effects of A1 and A2 alleles of betacasein gene on milk protein and milk fat yields, more extensive investigation on higher numbers of animals is needed.

To the best of our knowledge, this is the first study of this type in Serbia. Our results indicate that study could be expanded on a large-scale number of animals within the population of different cattle breeds, including population of Serbian indigenous cattle breeds. It could provide farmers with an opportunity for better breeding and selection programs and, finally, production of milk with better properties in Serbia.

\section{Acknowledgements}

This study was supported and financed by the International Atomic Energy Agency (Contract No. 20774) which forms part of the IAEA Coordinated Research Project D31028.

\section{Authors' contributions}

RM designed the study and drafted the manuscript. RM and GU performed laboratory analyses. RM and MM were responsible for the sampling and data collection. VB 
performed statistical analysis. KD, TV and SZ have contributed to the interpretation of data, revision of the manuscript and supervision of the experiment, as well.

\section{Declaration of conflicting interests}

The author(s) declared no potential conflicts of interest with respect to the research, authorship, and/or publication of this article.

\section{REFERENCES}

1. Farrell HMJ, Jimenez-Flores R, Bleck GT, Brown EM, Butler JE, Creamer LK, Hicks CL, Hollar CM, Ng-Kwai-Hang KF, Swaisgood HE: Nomenclature of the proteins of cows' milk--sixth revision. J Dairy Sci 2004, 87: 1641-1674.

2. Denhardt DT, Guo X: Osteopontin: a protein with diverse functions. FASEB J 1993, 7(15): 1475-1482.

3. Lönnerdal B, Iyer S: Lactoferrin: molecular structure and biological function. Annu Rev Nutr 1995, 15(1): 93-110.

4. Nuijens JH, van Berkel PH, Schanbacher FL: Structure and biological actions of lactoferrin. J Mammary Gland Biol Neoplasia 1996, 1(3): 285-295.

5. Elliott RB, Harris DP, Hill JP, Bibby, NJ, Wasmuth HE: Type I (insulin dependent) diabetes mellitus and cow milk: casein variant consumption. Diabetologia 1999, 42: 292-296.

6. Rijnkels M: Multispecies comparison of the casein gene loci and evolution of casein gene family. J Mammary Gland Biol Neoplasia 2002, 7(3): 327-345.

7. Gallinat JL, Qanbari S, Drögemüller C, Pimentel ECG, Thaller G, Tetens J: DNA-based identification of novel bovine casein gene variants. J Dairy Sci 2013, 96(1): 699-709.

8. Haq MR, Kapila R, Shandilya UK, Kapila S: Impact of milk derived $\beta$-casomorphins on physiological functions and trends in research: a review. Int J Food Prop 2014, 17(8): 17261741.

9. Singh LV, Jayakumar S, Sharma A, Gupta SK, Dixit SP, Gupta N, Gupta SC: Comparative screening of single nucleotide polymorphisms in $\beta$-casein and $x$-casein gene in different livestock breeds of India. Meta gene 2015, 4: 85-91.

10. Malarmathi M, Senthil KT, Parthiban M, Muthuramalingam T, Palanisammi A: Analysis of B-casein gene for A1 and A2 genotype using allele specific PCR in Kangeyam and HolsteinFriesian crossbred cattle in Tamil Nadu. Indian J Anim Sci 2014, 43: 310-315.

11. McLachlan CNS: Beta-casein A1, ischemic heart diseases, mortality and other illnesses. Med Hypotheses 2001, 56: 262-72.

12. Thorsdottir I, Birgisdottir BE, Johannsdottir IM, Harris DP, Hill J, Steingrimsdottir L, Thorsson AV: Different $\beta$-casein fractions in Icelandic versus Scandinavian cow's milk may influence diabetogenicity of cow's milk in infancy and explain low incidence of insulindependent diabetes mellitus in Iceland. Pediatrics 2000, 106(4): 719-724.

13. Roginski H: Encyclopedia of dairy sciences. Academic Press, London, 2003.

14. Kostyra E, Sienkiewicz-Szłapka E, Jarmołowska B, Krawczuk S, Kostyra H: Opioid peptides derived from milk proteins. Pol J Food Nutr Sci 2004, 13(Suppl 1):25-35. 
15. Laugesen M, Elliott R: Ischaemic heart disease, Type 1 diabetes, and cow milk A1 betacasein. N Z Med J (Online) 2003, 116: 1168.

16. Tailford KA, Berry CL, Thomas AC, Campbell JH: A casein variant in cow's milk is atherogenic. Atherosclerosis 2003, 170:13-19.

17. Sun Z, Zhang Z, Wang X, Cade R, Elmir Z, Fregly M: Relation of $\beta$-casomorphin to apnea in sudden infant death syndrome. Peptides 2003, 24: 937-943.

18. Cade R, Privette M, Fregly M, Rowland N, Sun Z, Zele V: Autism and schizophrenia: Intestinal disorders. Nutr Neurosci 2000, 3: 57-72.

19. Pal S, Woodford K, Kukuljan S, Ho S: Milk intolerance, beta-casein and lactose. Nutrients 2015, 7(9): 7285-7297.

20. Jianqin S, Leiming X, Lu X, Yelland GW, Ni J, Clarke AJ: Effects of milk containing only A2 beta casein versus milk containing both $\mathrm{A} 1$ and $\mathrm{A} 2$ beta-casein proteins on gastrointestinal physiology, symptoms of discomfort, and cognitive behavior of people with self-reported intolerance to traditional cows' milk. Nutr J 2015, 15(1): 35.

21. Barnett MP, McNabb WC, Roy NC, Woodford KB, Clarke AJ: Dietary A1 $\beta$-casein affects gastrointestinal transit time, dipeptidyl peptidase-4 activity, and inflammatory status relative to A2 $\beta$-casein in Wistar rats. Int J Food Sci Nutr 2014, 65(6): 720-727.

22. Becker A, Hempel G, Grecksch G, Matthies H: Effects of beta-casomorphin derivatives on gastrointestinal transit in mice. Biomed Biochim Acta 1990, 49(11): 1203-1207.

23. Mihatsch WA, Franz AR, Kuhnt B, Högel J, Pohlandt F: Hydrolysis of casein accelerates gastrointestinal transit via reduction of opioid receptor agonists released from casein in rats. Neonatology 2005, 87(3): 160-163.

24. Haq MRU, Kapila R, Kapila S: Release of $\beta$-casomorphin-7/5 during simulated gastrointestinal digestion of milk $\beta$-casein variants from Indian crossbred cattle (Karan Fries). Food Chem 2015, 168: 70-79.

25. Velmala R, Vilkki J, Elo K, Mäki-Tanila A: Casein haplotypes and their association with milk production traits in the Finnish Ayrshire cattle. Anim Genet 1995, 26(6): 419-425.

26. Ikonen T, Ojala M, Ruottinen O: Associations between milk protein polymorphism and first lactation milk production traits in Finnish Ayrshire cows. J Dairy Sci 1999, 82(5): 1026-1033.

27. Ikonen T, Bovenhuis H, Ojala M, Ruottinen O, Georges M: Associations between casein haplotypes and first lactation milk production traits in Finnish Ayrshire cows. J Dairy Sci 2001, 84(2): 507-514

28. Nilsen H, Olsen HG, Hayes B, Sehested E, Svendsen M, Nome T, Meuwissen T, Lien S: Casein haplotypes and their association with milk production traits in Norwegian Red cattle. Genet Sel Evol 2009, 41(1): 24.

29. Hanusová E, Huba J, Oravcová M, Polák P, Vrtková I: Genetic variants of beta-casein in Holstein dairy cattle in Slovakia. Slovak J Anim Sci 2010, 43(2): 63-66.

30. Oleński K, Kamiński S, Szyda J, Cieslinska A: Polymorphism of the beta-casein gene and its associations with breeding value for production traits of Holstein-Friesian bulls. Livest Sci 2010, 131: 137-140.

31. Visker MHPW, Dibbits BW, Kinders SM, Van Valenberg HJF, Van Arendonk JAM, Bovenhuis $\mathrm{H}$ : Association of bovine $\beta$-casein protein variant I with milk production and milk protein composition. Anim Genet 2011, 42(2):212-218

32. Khatkar MS, Thomson PC, Tammen I, Raadsma HW: Quantitative trait loci mapping in dairy cattle: review and meta-analysis. Genet Sel Evol 2004, 36(2): 163-190. 
33. Schopen GCB, Heck JML, Bovenhuis H, Visker MHPW, Van Valenberg HJF, Van Arendonk JAM: Genetic parameters for major milk proteins in Dutch Holstein-Friesians. J Dairy Sci 2009, 92(3): 1182-1191.

34. Lien S, Aleström P, Klungland H, Rogne S: Detection of multiple $\beta$-casein (CASB) alleles by amplification created restriction sites (ACRS). Anim Genet 1992, 23(4): 333-338.

35. Ristanic M, Stanisic L, Maletic M, Glavinic U, Draskovic V, Aleksic N, Stanimirovic Z: Bovine foetal sex determination-Different DNA extraction and amplification approaches for efficient livestock production. Reprod Domest Anim 2018, 53(4): 947-954.

36. Gustavsson F, Buitenhuis AJ, Johansson M, Bertelsen HP, Glantz M, Poulsen NA, Månsson HL, Stålhammar H, Larsen LB, Bendixen C, Paulsson M: Effects of breed and casein genetic variants on protein profile in milk from Swedish Red, Danish Holstein, and Danish Jersey cows. J Dairy Sci 2014, 97(6): 3866-3877.

37. Molee A. Boonek, L, Rungsakinnin N: The effect of beta and kappa-casein genes on milk yield and milk composition in different percentages of Holstein in crossbred dairy cattle. Anim Sci J 2011, 82: 512-516.

38. Chessa S, Bulgari O, Rossoni A, Ceriotti G, Caroli AM: Bovine $\beta$-casein: Detection of two single nucleotide polymorphisms by bidirectional allele specific polymerase chain reaction (BAS-PCR) and monitoring of their variation. Open J Anim Sci 2013, 3: 36-41.

39. Dai R, Fang Y, Zhao W, Liu S, Ding J, Xu K, Yang L, He C, Ding F, Meng H: Identification of alleles and genotypes of beta-casein with DNA sequencing analysis in Chinese Holstein cow. J Dair Res 2016, 83(3): 312-316.

40. Ramesha KP, Rao A, Basavaraju M, Alex R, Kataktalware MA, Jeyakumar S, Varalakshmi S: Genetic variants of $\beta$-casein in cattle and buffalo breeding bulls in Karnataka state of India. Indian J Biotechnol 2016, 15: 178-81.

41. Massella E, Piva S, Giacometti F, Liuzzo G, Zambrini AV, Serraino A, 2017: Evaluation of bovine beta casein polymorphism in two dairy farms located in northern Italy. Ital J Food Saf 2017, 6: 6904.

42. Kamiński S, Ruść A, Cieślińska A: A note on frequency of A1 and A2 variants of bovine beta-casein locus in Polish Holstein bulls. J Anim Feed Sci 2006, 15: 195-98.

43. Cieślińska A, Kostyra E, Kostyra H, Oleński K, Fiedorowicz E, Kamiński S: Milk from cows of different $\beta$-casein genotypes as a source of $\beta$-casomorphin-7. Int J Food Sci Nutr 2012, 63(4): 426-430.

44. Oleński K, Cieślińska A, Suchocki T, Szyda J, Kamiński S: Polymorphism in coding and regulatory sequences of beta-casein gene is associated with milk production traits in Holstein-Friesian cattle. Anim Sci Pap Rep 2012, 30: 5-12.

45. Hallén E, Wedholm A, Andrén A, Lundén A: Effect of $\beta$-casein, $x$-casein and $\beta$ lactoglobulin genotypes on concentration of milk protein variants. J Anim Breed Genet 2008, 125(2): 119-129.

46. Maletić M, Vakanjac S, Đelić N, Lakić N, Pavlović M, Nedić S, Stanimirović Z: Analysis of lactoferin gene polymophism and its association to milk quality and mammary gland health in Holstein-Friesian cows. Acta Vet-Beograd 2013, 63(5-6): 487-498.

47. Maletic M, Aleksic N, Vejnovic B, Niksic D, Kulic M, Djukic B, Cirkovic D: Polymorphism of $x$-casein and $\beta$-lactoglobulin genes in Busha and Holstein Friesian dairy cows in Serbia. Mljekarstvo 2016, 66: 198-205. 


\title{
POLIMORFIZAM BETA-KAZEINSKOG GENA I NJEGOVA POVEZANOST SA KARAKTERISTIKAMA ZA MLEKO KOD HOLŠTAJNFRIZIJSKIH KRAVA IZ SRBIJE
}

\author{
RISTANIC Marko, GLAVINIC Uros, VEJNOVIC Branislav, MALETIC Milan, \\ KIROVSKI Danijela, TEODOROVIC Vlado, STANIMIROVIC Zoran
}

Najzastupljeniji tipovi beta kazeina u kravljem mleku su A1 i A2 koji se razlikuju u jednoj aminokiselini. Tokom gastrointestinalne proteolize A1 beta kazeina kod ljudi, oslobađa se betakazomorfin 7, opioidni peptid koji može uzrokovati pojavu raznih oboljenja (dijabetes melitus tip 1, ishemijska bolest srca, ateroskleroza, sindrom iznenadne smrti odojčadi, autizam, šizofrenija, nelagodnost u digestivnom sistemu, kao i produženo vreme gastrointestinalne pasaže). Suprotno tome, A2 beta kazein, zbog svog sastava i drugačijeg metabolizma, ne može da ispolji navedene efekte. Istraživanja su pokazala takođe, da može imati uticaj na proizvodnju i sastav mleka. Ovo istraživanje imalo je za cilj da ispita frekvenciju beta kazeinskih genskih alela A1 i A2 u populaciji holštajnfrizijske rase u Srbiji i da utvrdi kako genotipovi utiču na proizvodnju mleka, mlečnih proteina i masti. Od 106 ispitanih životinja, kod 13 (12,26\%) je ustanovljen genotip A1A1, kod 58 (54,72\%) A1A2, a kod 35 (33,02\%) A2A2 genotip. Proizvodnja mleka bila je značajno veća kod životinja sa A2A2 genotipom u poređenju sa genotipovima A1A1 i A1A2 (P<0,01). Koncentracije proteina u mleku bile su značajno veće kod životinja sa A2A2 genotipom u poređenju sa životinjama A1A2 genotipa $(\mathrm{P}<0,01)$, dok su koncentracije mlečne masti bile značajno veće kod životinja A2A2 genotip u poređenju sa životinjama A1A1 i A1A2 genotipa $(\mathrm{P}<0,01)$. 